\title{
Iwona MILEWSKA
}

Jagiellonian University in Kraków, Poland

milewska.iwona@gmail.com

\section{TRESPASSING SPACES OR SOME INTERCULTURAL WALKS}

ABSTRACT The purpose of the article is to discuss, based on chosen examples, whether the intercultural understanding is possible and what are the limits of it. Firstly, in a short introduction, the tools which the Europeans elaborated in order to understand Indian texts, which were mainly grammars and dictionaries, are discussed. Then, the Sanskrit terms such as "dharma," used to express the most important ideas of Indian culture, are analyzed. This discussion is followed by the analyse of the noun "vana." Its most typical English equivalent used in translations is "forest." However, after deeper consideration, it appears that the understanding of this term differs depending on particular cultural roots. The next noun to be discussed is "lotus" as used in the European texts in which these Indian flowers are shown. In Sanskrit works of literature the European word "lotus" has more than one equivalent and the differences among Indian lotuses are of importance in the process of creating appropriate poetic images. One more example of potential "intercultural walks" described in the article is the presentation and comparison of the reception of two versions, an Indian and a European one, of the Mahabharata epic as arranged and received in modern times.

Keywords: culture, ancient Sanskrit texts, dharma 
$\mathrm{T}$ he vital question which may be asked when anybody tries to deal with any culture which is not her or his own is whether common understanding is at all possible. What are the limits and borders of such understanding? To what extent can we really claim we have understood "the other"? Many years have passed since people coming from what we label as "West" and "East" tried to meet. At least in some areas it seems that they managed to do so. However, in some fields it is not so easy to achieve it or it even seems impossible. Let me try to analyse some examples which may illustrate the topic.

Being a European, and, at the same time, an indologist or, to be precise, a sanskritologist whose specialization is first of all ancient India, I will focus on the presentation of the attempts of meetings between cultures of Europe and India. First of all, there is the general question concerning the areas in which the meetings are at all possible. To what extent trespassing spaces of each particular canon of values, beliefs and other factors of e.g. everyday, earthly life can be understood by strangers? Do abstract ideas of the respective cultures allow for an easy "intercultural walk"? What are the dangers awaiting the ones who want to overcome the differences in understanding the abstract terms like e.g. religion or the meanings of common words like e.g. table, clothes, forest etc. In this text I should present some examples of a range of potential misunderstandings.

I shall start with language problems as language is definitely one of the most important tools to understand each other. In one of the early Indian texts, namely the Chandogya Upanishad, there is a phrase illustrating this thought. It says there that purushasya vag rasah [The essence of man is speech] (ChUp. I:1.2). I will follow this line of thinking and check to what extent a meeting at the level of language is obtainable.

As it is impossible, in a text like this, to cover all the languages of India or Europe, I have chosen to focus only on one that is of major importance in the process of understanding ancient Indian culture - Sanskrit. As far as Europe is concerned, the most attention will be paid to English, being one of the very first European languages by means of which the knowledge about India was passed to Europe. On the other hand, Sanskrit is the language of the canon of ancient, mostly sacred, texts transmitted orally for ages and only then preserved in the written form. Its roots are in the language of Vedas, Brahmanas, Aranyakas and Upanishads. ${ }^{1}$ Sanskrit is a language of especially great importance. It is the language of the epics, ${ }^{2}$ namely

The dating of these texts is, up to modern times, not very precise. It seems that it covers the period which started about the $12^{\text {th }}-10^{\text {th }}$ century BC. and ended around the $6^{\text {th }}$ century BC.

2 It is worth adding that the term "epic" used here, as was once indicated by John Brockington in his book entitled Indian Epics (Brockington 1998) may not correspond exactly to what the Europeans label as the epic work. Brockington writes Throughout the history of Indology Western scholars have generally called them the two Sanskrit epics, as in the title of this volume, a practice which has brought together under one label two works which the Indian tradition designates by different terms, neither of which can really be translated as epic - J.L. Brockington, The Sanskrit Epics, Leiden 1998, p. 1 (Handbuch der Orientalistik). As may be seen, for the lack of better terms Brockington uses the one which he himself has criticized. This may already be given as an example of difficulties of intercultural meetings. The solutions used are often the endeavours to be as near as possible in one's walks through the spaces of "the other." 
the Mahabharata ${ }^{3}$ and the Ramayana. ${ }^{4}$ These two were, and still are, known by wide circles of Indian society. This is why the acquaintance with them is so important for the understanding of ancient and modern culture of India, for understanding the people of the country, and for building bridges for intercultural walks. Sanskrit is also the language of the whole abundance of literature from the so-called "classical period." It is worth mentioning that within this period one can find works of many distinguished and famous authors, among them the Indian Shakespeare - Kalidasa. ${ }^{5}$ As may be observed, one of the problems in trespassing the space between India and the West is the difference in their respective attitudes towards time. ${ }^{6}$ To what extent can we under-

3 As far as the Mahabharata, which consists of approximately 75,000 stanzas, is concerned, the dating is again not clear. The latest theories, based on $20^{\text {th }}$ century research carried on by such scholars as e.g. James Fitzgerald, include the information about the frames of the text from the $2^{\text {nd }}$ century $B C$ to the $2^{\text {nd }}$ century AD. However, it is obvious that these are not the exact frames. The passages from much older periods and the ones from later centuries are undoubtedly included in this text.

4 Doubts concerning the Ramayana dating are similar to the previously mentioned. Researchers from the $19^{\text {th }}$ and the beginning of $20^{\text {th }}$ century claimed that its frames are $2^{\text {nd }} \mathrm{BC}$. to $2 \mathrm{AD}$. However, nowadays the scholars point to the fact of the unclear dating of particular fragments of it. They think that probably the best method, if somebody is really urged to date any Indian text, is to try to scrutinize the very fragment and consider the historical facts included together with the mentions of preceding works (if any) and e.g. the characteristic style of the particular passage. The last factor can indicate the hand of one author or, at least, one redactor.

5 Again, even if this time only one author is considered, it is very difficult to indicate the exact dates of Kalidasa's life. Through non-direct sources that is through information on him or his works incorporated in other texts and through details concerning historical facts most of the scholars agree that he must have lived at the turn of the $4^{\text {th }}$ and $5^{\text {th }}$ century AD. Some of the statements made by $20^{\text {th }}$ century scholars like A.A. Macdonell who, in his book A History of Sanskrit Literature, London 1900 (repr. 1990), after considering different theories, decides to date Kalidasa's life at the beginning of the $5^{\text {th }}$ century AD. Ibid., p. 274. Mauritz Winternitz, the author of a monumental work on the history of Sanskrit literature entitled History of Indian Literature edited for the first time between 1905-1922, again, after considering different European theories concerning the time of Kalidasa's life, concludes So, all that we know as certain is just that the fame of Kalidasa was well-established in the first half of the $7^{\text {th }}$ century $A D$ - M. Winternitz, Vol. 3, repr. Delhi 1963, pp. 47-48. The scholar who is most sceptical about dating the life of Kalidasa is A. B. Keith. In his book A History of Sanskrit Literature edited in 1928 he says We know nothing whatever of value from later sources regarding the life and character of Kalidasa - A.B. Keith, A History of Sanskrit Literature, repr. Delhi 1996, p. 79. This uncertainty about the dates of life of Kalidasa's life noted by the European scholars shows one more difference between Indian and European cultures. This is the attitude towards exact dating of their literary heritage. What was important in Indian perception was the content of the works rather than their dating. In contrast, the European attitude may be shown in regards to the first translation of one of Kalidasa's works namely the Sakuntala to English. It was made in 1789 and the author was William Jones. The exact details concerning its date and information on Jones's life and activities may be easily found. Whether the word "translation" is appropriate in this context may be a matter of discussion. Was it rather an "interpretation" in the modern meaning of the term? Very soon, in 1791, it was "re-translated" from English to German by Georg Forster becoming an influential work in the circles of European intellectuals.

6 M.K. Byrski in his article 'O czym mówi literatura indyjska, czyli współrzędne indyjskiej rzeczywistości, Literatura na Świecie, Vol. 10 (1980) among other terms discusses the term "time" as understood in Indian tradition (pp. 158-179). His proposal is to establish its meaning in connection with other terms that are important for the understanding of Indian culture. The terms analyzed by him are wisdom, freedom, time and space, life and suffering. 
stand each other if the Europeans are "obsessed" with dating whereas Indians seem to be rather careless about it?

Bearing in mind that language is such an important key to understand "the other" I shall start with the analysis of the first modern attempts to discover Sanskrit, this sacred language of Indians, at the linguistic level. To do so, I shall first discuss the visits of first European missionaries who came to India mostly in order to Christianise its people. Even if the missionaries, who came mostly to the south of India, started to collect information on local languages such as e.g. Malayalam or Tamil, they soon realized that their contacts with Indian people, if they wanted to be respected by them, should be rooted in the knowledge of the most important language of Indian religion - Sanskrit. It was the language of priests, of Brahmanas who enjoyed immense prestige among local people. It was the language of upper classes of the society. If missionaries wanted to achieve their main goal, that is Christianisation, it was advised for them to know this sacred language.

The first European missionaries who managed to communicate with the local people came mainly from Franciscan and Dominican orders. They reached southern parts of India in the sixteenth century. However, the first known descriptions of Sanskrit came from the Jesuits who came there a bit later namely at the turn of sixteenth and seventeenth centuries. An English Jesuit Thomas Stevens (1549-1619) was the first one to observe the similarities between Indian and European languages. His observations were of general nature. He observed that Sanskrit, as far as its construction is concerned, is similar to ancient European languages namely to Latin and Greek. ${ }^{7}$ The European scholar who is more widely known as the one who noticed these similarities is William

In the letter sent to his brother in 1583 he wrote the following sentences: Linguae harum regionum sunt permultae. Pronunciationem habent non invenustam et compositione latinae grecaeque similem; phrases et constructiones plane mirabiles. Literae syllabarum vim habent, quae toties variantur quoties consonantes cum vocalibus, vel mutae cum liquidis combinari possunt (There are many languages used in these countries. Their speech is not without charm; in composition it resembles Latin and Greek; phrases and constructions are worthy of our respect. The letters signify syllables, and they have as many shapes as there are possible combinations of consonants with vowels). His observations certainly show some, even if very preliminary, knowledge of Sanskrit. Despite being friendly towards the language achievements of locals, as their speech is not without charm and phrases and constructions are worthy of respect his remarks also show an attitude of superiority towards Indian culture which would be the predominant feature of the contacts for many years to come. The Europeans were the ones who put themselves in a position not only to describe but also to value Indian culture and its languages. This tendency is sometimes shown also in modern studies. The one who questioned this attitude in his book Orientalism is E. W. Said (New York 1978). The problem of this attitude was also discussed by W. Halbfass in his book on Indian culture entitled Indien und Europa. Perspektiven ibrer geistigen Begegnung (Basel 1981). Questions of this type are asked till nowadays by many other specialists e.g. by K. Karttunen in his article 'Some Thoughts about Edward Said, Hindutva, and Western Indology', Cracow Indological Studies, Vol. 10 (2008), pp. 265-275. Karttunen raises one more question which may make the chances of communication even more difficult. He writes The indologists of the past have been subject to the prejudices of their age - ibid., p. 272. Can we relate this remark only to the past? The prejudices of the West towards East or, in other words, the cliches concerning the "Eastern type of thinking" do certainly exist today. Some of them were discussed by Johannes Bronkhorst in his book The Greater Magadha. Studies in the Culture of Early India, Leiden 2007 (Handbuch der Orientalistik) and in some of his articles e.g. 'L'Indianisme et les préjugés occidentaux,' Études de Lettres. Revue de la Facultee des Lettres, Lausanne, No. 2 (1989), pp. 119-336. 
Jones (1746-1794). In 1786, at one of the meetings of Asiatic Society of Bengal, he announced that Sanskrit is, in many respects, similar to Greek, Latin, German, Celtic and Persian languages. ${ }^{8}$ Since then, he is treated as the first person who managed to build the bridge for comparative linguistics.

Simultaneously with these general observations, the first endeavours to discover the grammar of Sanskrit took place. From what is known (known in the meaning of "uncovered already") the first missionary to write a complex Sanskrit grammar was Father Heinrich Roth (1620-1668). He was a Jesuit who spent ten years in Goa and Agra. One of the results of his stay was a Sanskrit grammar written in Latin and, unfortunately, kept in a manuscript form for several centuries to come. It was dated 1660-1662. In his endeavour to describe Sanskrit Roth certainly used the help of local pandits, what is obvious from the content of his grammar and the way grammar topics are presented. It shows the features visible in at least two traditional Sanskrit grammatical works namely Särasvata Vyākarana of Anūbhuti Svarūpācārya (most probably coming from the $14^{\text {th }} / 15^{\text {th }}$ century $)^{9}$ and Mugdhabodha whose author was Vopadeva ( $13^{\text {th }}$ century). ${ }^{10}$ These two grammars were popular in India as didactic tools at the period of Roth's stay there. What is worth stressing here is the fact that Roth, in order to write his grammar, had to establish extremely good contacts with the local pandits. These pandits must have been open to contacts with the Europeans and, at the same time, very "brave." Why do I label them "brave"? Because they went against the Indian tradition according to which sharing the knowledge of Sanskrit with strangers was forbidden. Many traditional pandits treated Europeans as barbarians. They even had a special Sanskrit term (mleccha) for strangers who did not have the right to learn the language of their religion. Strangers, especially Europeans, were definitely not treated as members of the upper class of Indian society. One of the potential bridges of common understanding, namely the knowledge of Sanskrit at this initial stage of contacts was well-guarded with the result of making any intercultural contacts based on the command of such an important language particularly difficult. Unfortunately, there are no detailed descriptions of these first meetings nor examples of any co-operation in the field of sharing the knowledge of Sanskrit with barbarian Europeans. Were these "brave" pandits paid for their help or did some of them simply want to share their command of this sacred language? Did they want to show off or did they decide to allow some Europeans to enter the world of their religion and of their literary texts? We are left here with speculation rather than knowledge based on documented facts. However, what one can notice is that in most, if not in all, examples of Sanskrit grammars written by the Europeans in this period, on the title page one can find only some general information that their $\mathrm{Eu}-$

8 More information on W. Jones gives F. Edgerton in the chapter concerning him, included in the book Th.A. Sebeok, Portraits of Linguists. A Biographical Source Book for the History of Western Linguistics, 1746-1963 Vol. 1, Bloomington 1966 (Indiana University Studies in the History and Theory of Linguistics).

9 Look H. Scharfe, Grammatical Literature, in J. Gonda (ed.), A History of Indian Literature, Vol. 5, fasc. 2, Wiesbaden 1977, p. 189.

10 Look ibid., p. 188. 
ropean authors were helped by Indian pundits. The names of these pandits are not given. Was it one more sign of the European attitude of superiority towards natives or was it an indication that the pandits themselves did not want to let their names be known to their compatriots in fear of being the breakers of the traditional rules? ${ }^{11}$ Roth's grammar, even if extremely accurate in its presentation of Sanskrit, certainly and unfortunately, was not a tool for building language bridge between Indians and Europeans due to the fact that it was kept only in the manuscript form. It was a big pity, as the next one, this time written by the Carmelite priest, Paulinus a Sancto Bartholomaeo (1748-1806), was edited over a hundred years later. Only this version was to become the first one widely known in Europe. It was due to the fact that it was printed, distributed and discussed by the Europeans, contemporaries of Paulinus. The grammar was entitled Sidharubam seu Grammatica Samscridmica. Cui accedit Disertatio historico-critica in linguam Samscridamicam, vulgo Samscret dictam and edited in $1790 .{ }^{12}$ It was followed by the second book published in 1804, which was an enlarged form of the previous grammar. Its title was Vyacarana seu locupletissima Samscridamicae linguae institutio. Paulinus was strongly criticized by his contemporaries, mainly the Englishmen who came to India as representatives of East India Company. They accused him, first of all, of incompetence. They pointed out, among other things, many mistakes in the grammatical forms he presented. There was some truth in it as in his grammar he confused even the name of Sanskrit itself. The names given by him were the following: Hanscret, Sanscroot, Samscroustan, Samscroudam, Samskretam, Samscretam, Sanscreet, Grandon, Samscret, Sanscrit, Shanscrit, Samscrit, Samskrdam, and Samscredam. ${ }^{13}$ But, due to the different spellings of the name of the language, he confused its name with the name of one of the alphabets. First "intercultural walks" were certainly full of random wanderings and misunderstandings. The first bridges of common understanding namely the books of grammar were hardly built yet. However, as may be noticed, the Europeans, even at this early stage of modern meetings, showed a strong will of discovering India. ${ }^{14}$

Obviously, it was an important period in regard to intercultural contact not only because of the Christianisation of India. India started to be an interesting area for mer-

11 Definitely one can notice that the Indian attitude of not being open to "others" was opposed by the European desire to discover and understand "the other." Another problem were the reasons behind the European will to discover languages of India. Can we think that it was only for the purpose of converting Indians to Christianity? Maybe the problem is not so explicit. Certainly, at least some of the Europeans, were simply interested in this different culture, its literature, its ideas, values, ways of life.

12 It was re-edited in the $20^{\text {th }}$ century with a versatile commentary and translation made by an indologist Ludo Rocher. The book's title is Paulinus a Sancto Bartholomaeo, Dissertation on Sanskrit Language. A reprint of the original Latin text of 1790, together with an introductory article, a complete English translation, and an index of sources, by L. Rocher, Amsterdam 1977 (Amsterdam Studies in the Theory and History of Linguistic Science).

13 Ibid., pp. 81-82.

14 One should add here that Indians of that period were not interested in the languages of Europe. There are no proofs of their visits nor endeavours to establish links by discovering or describing the grammars of the European languages. 
chants. The Europeans came to this unknown country in order to explore its natural resources. They wanted to establish merchandise links. To obtain good results they wanted to understand its culture. Similarly to missionaries they soon discovered that one of the important keys to it was the knowledge of Sanskrit. The merchants were soon followed by scholars, mainly of British origin. Some of them started to have contacts with local pandits. However, the pandits were again divided in their attitude towards the Europeans.

Nevertheless, British scholars, as a result of their endeavours, started to prepare not only grammars but also bilingual dictionaries. The dictionaries were to become extremely important in the process of common understanding. The first one was prepared by Horace Hayman Wilson (1786-1860) and edited in Calcutta in $1819 .{ }^{15}$ It was a bilingual dictionary. The entries were arranged in alphabetical order. Another one which appeared at more or less the same time was A Sanskrit Vocabulary by William D.D. Yates (1792-1845). However, this one was following Indian tradition as far as the idea of a dictionary is concerned. It contained lists of nouns, adjectives, verbs and indeclinable particles most frequently occurring in Sanskrit. They were arranged in grammatical order and they had explanations in Bengali and English. Already these first endeavours show that the contact between Indians and Europeans improved as far as common acceptance and attitude towards each other was concerned. W. Yates not only noticed the Indian tradition but he followed it. On the other hand, H.H. Wilson tried to make Sanskrit vocabulary easier for the Europeans by using the European method of explaining the words. Unfortunately, both works did not become widely known in Europe. As in the example of the first Sanskrit grammar, many years must have passed till these means of understanding have become accessible to the European public interested in India and its culture. From the range of bilingual dictionaries the one which was and still is widely known and used was edited by Monier Monier-Williams (1819-1899). It was printed, for the first time, in Oxford in 1872. Since then it has had many re-editions, becoming an extremely important tool in understanding Sanskrit texts.

The next person who, at the beginning of Indo-European contacts, was important for the deeper understanding of Indian culture was Henry Thomas Colebrooke (1765-1837). He was the one who was able to read many literary Sanskrit works in original Sanskrit. One of the results of his readings was the grammar of Sanskrit edited in $1805 .{ }^{16}$

Simultaneously, William Carey (1761-1834) who was a teacher of Sanskrit (he was supposed to teach Englishmen who were in India during this period) wrote a different kind of grammar. Even its title indicates a difference - A Grammar of the Sungskrit language, composed from the works of the most esteemed Grammarians. To which are added, examples for the exercises of the student, and a complete list of the dhatoos, or roots. It was edited in Serampore in 1806. As may be seen, the difference between the grammars laid

15 A Dictionary in Sanskrit and English, translated, amended, and enlarged from an original compilation, prepared by learned natives for the College of Fort William by H.H. Wilson, Calcutta 1819.

16 H.Th. Colebrooke, A Grammar of the Sanscit Language, Vol. 1, Calcutta 1805. 
in their attitude towards the local grammatical tradition. It was similar to the attitude of grammars described above (Roth's versus Paulinus's). Colebrooke's grammar was following the European standards while Carey's one, but for being didactic rather than descriptive, followed the Indian grammatical tradition. Regardless of the attitude towards Indian or European grammatical traditions, the bridges started to be built. It was shown also by respect which is an indispensable condition for any successful meeting of different cultures. Many grammars of Sanskrit (over one hundred) have been prepared since these first ones. They obviously brought more exact information on this language of ancient Indian culture. However, the question whether the modern understanding, thanks to their existence, can be described as perfect is still open. ${ }^{17}$

Some of the Europeans went to India on their own but there were and still are many who knew it from second-hand information. Some of them were from the very beginning "fascinated" by it. These were e.g. the first German scholars, poets and general public who wanted to discover India in the period of Romanticism. Many of them became strongly influenced by Sanskrit literature or linguistics. They studied first European Sanskrit grammars and manuscripts brought to Europe at this time. ${ }^{18}$

But for grammars and dictionaries of this period some university professors prepared their own chrestomathias of passages of texts which were, in their opinion, most important for understanding Indian culture. The question which may be asked here is whether their choices could have been objective in terms of showing European public what were the most valuable texts for Indians. To what extent was it possible to prepare a meaningful and proper selection? When one compares these chrestomathias it is easy to observe that a number of the authors repeated the choices which had been made by the authors of the preceding works. It means that the first chrestomathias became the most influential means to present ancient India to Europeans. ${ }^{19}$ The choices, due to their arbitrariness, created an image of an unknown past of an unknown culture. It was comparatively easy to mislead the ones who were interested in India or to guide them in a not necessarily proper (meaning adequate) way. In the period when the first chrestomathias were published it was very popular to take fragments from Indian folk-

17 More extended information, together with the detailed analysis of the structure of these grammars is to be found in the article 'Main Currents in the European Tradition of Sanskrit Grammars', in G. Cardona (ed.), Vyäkarana Across the Ages, New Delhi 2013 written by the author of this text.

18 The most famous author of comparative grammar is Franz Bopp (1791-1867) who already in 1816 published his first book dealing with the conjugation of Sanskrit verbs. The book for which he is most famous is Kritische Grammatik der Sanskrit Sprache in kürzerer Fassung edited in Berlin in 1832 and re-edited since then many times.

19 Most probably one of the first ones was prepared by Maurice Thomas (1754-1824) in the second half of $18^{\text {th }}$ century. It was entitled Sanscreet Fragments, or Interesting Extracts from Sacred Books of the Brabmins on Subjects Important to the British Isles. As is visible even from the title, the goal was to see what in Sanskrit texts was important for British people. Fortunately, this selection of fragments of texts was not followed by other Westerners. In the same period several other chrestomathias were edited. Among them one of the most well-known was prepared by Otto Boehtlingk (1815-1904) and edited for the first time in 1845 . It had many re-editions, and many selections prepared later by other scholars were similar in their choice of texts. 
-tales (mostly from Pańcatantra, Hitopadeśa, Kathasaritsagara or Śukasaptati) and epic literature - mostly the Mahabharata, sometimes the Ramayana and rarely the Puranas. These texts were considered the easiest from the grammatical point of view. Were they really showing the versatile image of Indian culture? In some of the chresthomatias fragments from other Indian literary works were inserted. Some of them coming from love literature (Gitagovinda or Amaruśataka) or passages chosen from dramas, texts on theory of poetics or philosophical ones. As the choice of texts depended on individual scholars and their own interests, it often did not show the spectrum of genres of Indian literature. However, it should be added that in many of these selections one can find passages chosen from Manusmriti (Manavadharmaśastra) which certainly is one of the most important texts of Indian culture. This definitely mean that at least some of the Europeans of this period were acquainted with the relative importance of the texts. One more text, Bhagavadgita, was, is and definitely will be extremely important. ${ }^{20}$ Its value and importance was noticed from the very beginning of the Europe - India encounter. The question is whether a European who reads and interprets Gita (as it is often called) has a possibility to understand it deeply while she or he does not have the knowledge of the whole Indian tradition.

As already mentioned, many of the initial European endeavours to discover India were made by the Europeans who went there. They met local people, saw their customs and habits. They observed their way of life and the eager ones could really overcome at least some of the difficulties in common communication and understanding. They saw local flora and fauna, experienced the weather, observed the seasons and their typical features, could "smell" the land. To give at least one example of a European who is well-known for his extreme openness to Indian culture I shall mention the name of Roberto de Nobili (1577-1656). He did not spend his time in India sticking to his own European identity but he tried to get nearer to local people by showing respect to them even in the way of wearing garments typical for Indians, instead of his European clothes. In this way, he really managed to make at least some Indians his good friends. Without a doubt he did not show any signs of superiority as he was the one to start the tradition of equality and respect in everyday contacts.

In general, one of the most important efforts made at the beginning of modern Indo-European contacts by the Europeans was their attempt to understand the culture

20 It is beyond the scope of this article to deal with the history of the Bhagavadita's translations to the European languages and the way it functions in both Indian and European culture. It definitely needs a separate analysis. Here, it is enough to say that the first translation of its fragment was published already in the second half of the $18^{\text {th }}$ century and since then it has been translated and edited hundreds of times in many European countries. In most of the translations one can find different attempts to explain its main message. Moreover, different proposals of meanings of particular words are given. It shows how wide is the potential spectrum of meanings not only of the Bhagavadgita but of many other Sanskrit texts. Additionally, it shows the difficulties which may appear in the process of common understanding of the key-texts of specific culture. It is worth adding that the Bhagavadgita and its influence on many Indian people may be compared to the Bible and its importance for the European culture. It is often the story told for the first time to children by their parents or grandparents and then re-told many times. Many Indians know it, or at least its fragments, by heart. It may be called a catechism of Indian people. 
of the unknown land by trying to describe its sacred language, Sanskrit, in the linguistic way. They treated it as one of the first tools for intercultural walks. Whether they really achieved it may be a matter of discussion. At least the attempt was made and the will was shown. The potential bridges of understanding built on the basis of the knowledge of Indian sacred language as far as its grammar, vocabulary and major texts are concerned became available in Europe.

However, the problems of intercultural communication are connected not only with the knowledge concerning grammatical topics and grammatical structures of unknown languages. Even if these languages come from the same language family (here the Indo-European family), the problems often multiply when it comes to vocabulary. It often happens that words which are described as having the same meaning in both languages are in fact not identical in their possible understanding. It also happens that there are words which do not have any counterparts in the other language. Even with the help of dictionaries one cannot be, at least in some cases, certain as far as the translation of particular words is concerned.

What can be analyzed first in order to shed some light on the problem is one of the most important Sanskrit words. This word is "dharma." One who wants to have a better understanding of Indian culture should definitely not be discouraged by the spectrum of its meanings which covers an immensely large field. When one looks for equivalents in the Monier-Williams's Dictionary ${ }^{21}$ one will find that this very entry is semantically a great challenge. To cite here only the major English counterparts given in this dictionary, "dharma" can be understood as: that what is established or firmed, steadfast decree, statute, ordinance, law; usage, practice, customary observance or prescribed conduct, duty; right, justice (often as a synonym of punishment); virtue, morality, religion, religious merit, good works. ${ }^{22}$ One of the contemporary Western indologists Richard Gombrich in one of his lectures discussed the complexity of this problem. ${ }^{23} \mathrm{He}$ described his own endeavours to understand it. Among other observations he stated that dharma $[. .$.$] is an image of the world's construction and a program for human conduct that$ are mere reflexes of one another. ${ }^{24} \mathrm{He}$ continued, dharma then is everything that is and should be the case. ${ }^{25}$ In conclusion, he did not seem to be an optimist as he states If the

21 M. Monier-Williams (ed.), A Sanskrit-English Dictionary Etymologically and Philologically Arranged with Special Reference to Greek, Latin, Gothic, German, Anglo-Saxon, and Other Cognate Indo-European Languages, London 1872 (repr. 1995).

Ibid., p. 510.

23 R. Gombrich, On Being Sanskritic. A Plea for Civilized Study and the Study of Civilisation. An Inaugural Lecture Delivered before the University of Oxford on 14 October 1977, Oxford 1978 (Inaugural Lectures, University of $O x$ ford). Another modern indologist who dealt with the word "dharma" is James Fitzgerald. His attention is given to the way this word was understood in the Mahabharata in particular. His conclusion is that what should always be taken into consideration is the context not only of the whole sentence which includes the word "dharma" or of the nearest passages of the text but also of what he calls the "wider circumstances." J. Fitzgerald, 'Dharma and its Translation in the Mahabharata,' Journal of Indian Philosophy, Vol. 32, No. 5/6 (2004), pp. 671-685.

24 R. Gombrich, On Being Sanskritic..., p. 9.

25 Ibid., p. 10. 
semantic field of a word is so wide as to designate everything that both is and should be the case, no wonder that it gives trouble to translators. ${ }^{26}$

The term "dharma" is an example of an abstract concept. But the problems do not end at the level of abstract terms. They concern also the words which seem, at first glance, obvious in their possible understanding and translation. Such is the example of Sanskrit word "vana." J.A.B. van Buitenen (1928-1979), one of the best modern translators of the Mahabharata to English, in the introduction to the third book of the epic, the Vanaparvan, describes its potential meanings together with possible associations the word has for an Indian recipient. Up to him the European recipient has different associations. ${ }^{27}$ He writes that the image behind this word for Indians, first of all, brings an association with an area which is not included in the village, town or city. He writes, Forest is the wilderness that has not been brought under cultivation, it may be described as "not yet" the village. But simultaneously it is "no more" the village. ${ }^{28}$ In some European languages the words which are given as equivalents are such as English "forest," French "la forêt," German "der Wald," Russian "les" or Polish "las." Sometimes the words like "jungle" or similar ones are used in the Indian context. When used in translations of Sanskrit texts most probably they are associated by the Europeans, first of all, with an image of Indian "vana" not as a place not yet cultivated but a place full of exotic trees and plants. The meaning is thus, first of all, connected with the physical image of this area. The word "vana" used to signify the distance from civilized areas is not what is directly imagined or stressed. In the European texts it needs further descriptions and explanations. J.A.B. van Buitenen's remark on the proper understanding is not the only difficulty that translators encounter. To show the complexity of the problem let me refer again to the Monier-Williams dictionary. The "vana" entry covers the following meanings of this word: a forest, wood, grove, thicket, quantity of lotuses or other plants growing in a thick cluster (but in older language also applied to a single tree); plenty, abundance; a foreign or distant land. What to do with such a spectrum of possible meanings if one encounter passages in which it cannot be clarified by the context? How to be certain what was described in the text? To make matters worse, Sanskrit word "vana" is very often not given directly in the text. There is a literary tradition of describing such areas by enlisting a multitude of trees described only by their Indian names like e.g. "aśoka" or "campaka" etc. These names sound, in most cases, exotic to the European recipients. What to do in such situation? The trees often do not have their direct counterparts in modern European languages. At least in some examples European readers do have Latin equivalents, for instance "aśoka" is identified with "ficus religiosa." However, even in such examples it is not sure whether the public can imagine this very tree being given only its Latin name. How to build the intercultural bridges here? Can we really walk through these forests? In situations in which the names of trees do not have their

26 Ibid., p. 10.

27 J.A.B. van Buitenen, 'Introduction' in The Mahabharata, Book 3: The Book of the Forest, ChicagoLondon 1975, pp. 173-215.

28 Ibid., p. 175. 
equivalents even in Latin, like the tree mentioned above, namely "campaka" most probably some additional information concerning its general look, its colors etc. should be given. What to do if a list consists of an abundance of such strange names? ${ }^{29}$ How to avoid the associations which are not adequate? Indian forests may be very different from each other. The same applies to the European ones. There is no easy answer as far as the method to avoid misunderstandings is concerned.

Similar problem occurs when the word which seems to be well-understood in most European countries is translated simply as "lotus." In India, everybody knows that there are many different kinds of lotuses. The English-Sanskrit dictionary enlists more than 50 different names for it. ${ }^{30}$ Moreover, such problems do not consider only lotuses. In literary texts of any culture it is often important whether the exact flower is e.g. of red, white or blue colour or if it is the one which blooms in the morning, evening or in the night. As far as lotus is concerned, the question is how to describe, without demolishing the literary value of the text, the differences between "padma," "kumuda" or "nalinam" which are different species of lotuses? This very word "lotus," with the associations and images it brings to mind, is of special importance as it is extremely often used in descriptions of Indian literary heroines and heroes. Can it be possible that the intercultural bridge exists here? Can the space of imagination based on reality be crossed? Can the average public or even refined circles of readers understand it in the same sense as people who belong to the other part of the world and to the other culture? The problem obviously is two-sided. Is it possible that a man from India who has never been outside her or his own country imagines a look (and smell!) of a particular kind of a European pine or flower? What does "an intercultural walk" mean in this respect? Obviously a good idea to overcome these sort of problems is to visit the country of interest. However, it is often not so easy to observe flora of the region as even in botanical gardens not all species are gathered. Moreover, what is also important are the natural places where particular plants grow. Obviously, the difficulties concern not only a "lotus" flower. Sometimes, names for different plants are used to signify a particular colour. This is the most important "hidden information." What to do in such situations? "Kandali" is a plant which has white flowers whereas the flowers of "kadamba" are orange. The recipients who are familiar with them have their images in mind immediately. But what can a stranger do? Obviously not only the colours are important but also, as already mentioned, e.g. the time the flowers start to bloom. It often adds the important information e.g. on the time of action of a certain literary work. The way flowers are described may also signify the potential mood of the heroine or hero etc.

The further and deeper we try to expand our understanding, the more problems occur. However, many times it seems manageable to trespass these spaces of differences.

29 It is a common habit to enlist the Sanskrit names of trees and create an image of "vana" by it. Look e.g. Mbh.III.155.37-155.45 where several dozen of names of trees are given. Renate Syed was one of the first contemporary Europeans who tried to deal with the problems of Indian flora. Already in 1990 her very helpful book R. Syed, Die Flora Altindiens in Literature and Kunst, Doktorgrades der Philosophie Universität München was published. 
One of the translators of fragments of the Mahabharata, W.J. Johnson in his introduction to the translation of the Sauptikaparvan wrote, For the non-specialist western reader the Mahabharata can resemble a vast but distant mountain range obscured by clouds. ${ }^{31}$ Evan if these words do not suggest his optimistic outlook on overcoming the problems of common understanding he decided to publish his translation in popular series namely in Oxford World's Classics. His translation includes only the main text. It does not contain many additional explanations, which sometimes may be a nightmare for the readers. Similarly to Johnson, Wendy Doniger, an American indologist and translator, in the introduction to her book of translations of chosen hymns from the Rigveda wrote This is a book for people, not for scholars. Real scholars will read the Rig Veda in Sanskrit; would-be scholars, or scholars from other fields will fight [stress - I.M.] their way through the translations of Geldner (German), Renou (French), Elizarenkova (Russian) and others; they will search the journals for articles on each verse, and on each word; they will pore over dictionaries and the concordances. ${ }^{32}$ Her translation was also published within the frame of popular series addressed to general public rather than to specialists namely in Penguin Classics. As may be seen after dividing the potential recipients into separate groups she tried to make an effort of building a bridge to ancient Sanskrit texts for the general public of the European origin. She definitely thought it was possible even if simultaneously she pointed out many difficulties. One of the questions she had risen is How can we understand the words if we do not understand the meaning behind them? ?3 $^{33}$ and she exemplified this question in the following way: The phrase, "We have become immortal," for example, is linguistically straightforward; few would challenge the plain English rendering. But what does it mean? What did they mean by immortality? Surely not eternal life, but what kind of afterlife? ${ }^{34}$ This is definitely one more difficulty to be overcome in cross-cultural meetings.

Planning to discuss more than just the seminal problems of immortality and literary translations of ancient Indian texts to the European languages, I shall turn now to one more example of an attempt to trespass the spaces of different cultures. I want to present two different modern approaches to the Mahabharata. One of them will be a European version of it. Another one - an Indian version. Both are modern films based on the epic. Both were filmed in the last decade of the $20^{\text {th }}$ century. In order to present them I will shortly summarize both performances.

The European version was prepared by one of the most famous European theatre and film directors, Peter Brook. In 1974, working together with Jean-Claude Carrière, a well-known European playwright, he started to think about creating his own version of the Mahabharata. They both wanted to make it easy to be understood not only by

31 W.J. Johnson, 'Introduction' in The Sauptikaparvan of the Mahabharata. The Massacre at Night, trans. with an introduction and notes by W.J. Johnston, Oxford-New York 1998, p. IX (Oxford World's Classics).

32 W. Doniger O'Flaherty, 'Introduction' in The Rig veda. An Anthology, Harmondsworth-New York 1984, p. 11 (Penguin Classics).

33 Ibid., p. 14.

34 Ibid., p. 15. 
Europeans but by people from all over the world. It took them 10 years to get ready for the enterprise. At the beginning, they were listening to the Mahabharata stories told to them by the French indologist Phillipe Lavastine. Their meetings went on for 6 months. Only then they read the French and English translations of the Mahabharata. They also went to India several times. After this long period they began rehearsals for the theatre performance which was then followed by a film version. The rehearsals lasted for nine months. Brook's main idea was to show the Mahabharata as an intercultural work, the heritage of whole mankind rather than of one culture. Obviously, he focused on the themes common to both Western and Eastern cultures rather than different topics which are exclusive to Indian culture. He gathered an international group of actors coming from 20 countries as, also in this way, he wanted to stress that the common values and motifs do re-appear in the lives of people regardless of their place of birth and the national tradition with which each of them is connected. The first performance open to public was in 1985. The nine-hour-long show took place in Avignon during the theatre festival. The language used was French. Then, with this version of the play the troupe travelled around Europe. They visited, not only France but also Greece, Italy, Germany and Spain. Later, they prepared an English version of the performance and in 1987 they began their next tour during which they went to Switzerland, USA, Australia, Denmark, United Kingdom and Japan. As can be noticed, they did not visit India. The concept was that each show was performed according to changing factors. It depended on the atmosphere of the evening, the mood of the public and the individual decisions of the actors who could slightly modify their parts. The only condition was that all the main narrative lines were retained. The performances often took place in extraordinary settings e.g. in open-air spots (quarries in Avignion or in Perth). Due to it, the natural phenomena (like dawn or dusk) constituted parts of each performance. Quite often the show lasted for three consecutive evenings and nights. Sometimes it was all day or all night long, lasting from dawn to dusk or from dusk to dawn. It was always divided into three parts entitled respectively "The Game of Dice," "Exile in the Forest" and "The War." Everywhere in the West the performance was received with great enthusiasm and it was well-reviewed..$^{35}$ Peter Brook's version of the epic was definitely directed at intellectual elites rather than at broader public. The idea was to maintain simplicity in all possible meanings. Brook wanted to find what was, in his view, archetypal. This will was revealed not only through the themes chosen to be presented, but also by the settings and costumes of the actors. Carriére decided that the thread of the whole epic and the performance is "dharma" so he wrote most of the scenes according to his choice. He also took five key-words around which he built the scenario. These were: life, blood, heart, fire and end. He focused on the main plot, barely adding the minor sub-stories of which the Mahabharata is full. However, from time to time he "enriched" the main characters with the features of other Mahabharata heroines and heroes which are not present in his version. Nearly half of the scenes did

35 The reviews can be found e.g. in M.L. Varapande, Mahabharata in Performance, New Delhi 1990, or G. O'Connor, The Mahabharata. Peter Brook's Epic in the Making, London 1989. 
not correspond verbatim to the original epic. Most of the colours used in the choreography prepared by Chloe Obolensky were reduced to white, brown and black. She decided that the three elements would be her priorities: earth, water and fire. The number of main protagonists was also reduced to twenty whereas the original epic has hundreds if not thousands of them. They were chosen in order to illustrate existential problems of every human. The point was to show the complexity behind the reasons for decisions related to "dharma" taken by every human being. Man's hesitations and final choices were highlighted and sometimes explained. The main subject was the eternal fight of good and evil shown as an unavoidable part of human existence.The simplicity of Brook's version of the Mahabharata was strongly criticized by some Indian reviewers. Rustom Bharucha wrote Brook's inadequate confrontation of Indian tradition is characterized by shortcuts. Instead of entering the "jungle" of Vyasa's text, with its labyrinthine paths and dense growth, he settles for the paraphrase. ${ }^{36}$ However, another Indian critic, A. Lal, wrote Brook must be viewed in his tradition. His Mahabharata is just that: his interpretation, not Vyasa's (who in any case may not have existed), nor "ours" (whatever that misleading plural may mean) ${ }^{37}$ Even if lightly criticizing Brook's version of the epic, A. Lal observed the ambiguity of the term "ours" in respect to the Indian tradition. $\mathrm{He}$ also gave the right to have one's own vision of the text. Maybe this is the path we should try to use while building bridges between cultures? To let everybody build her or his own image, placing limits only on the most important information and features of the work of art or the details of reality. On the one hand, there will be people who will think that the better the knowledge of the details of different culture, the better exposition it brings and the better is the chance of its "proper" image. These images should be based on concrete details like clothes, ornaments and other details of each of the respective culture. On the other hand, there always will be people whose search will focus on what is common for different cultures. They would not pay so much attention to minor details. This way, by looking for common values, they can also observe what is different, strange or not understandable for them. They can enlarge their horizons with new ideas or become sure of the main features of their own identity. The intercultural walks can happen, the spaces can be trespassed. The point is not to believe it is easy or always obtainable. However, there are certain borders that cannot be trespassed without a danger of great misunderstanding. In Brook's version, Krishna (in Indian tradition one of the most important gods) is shown as a semi-divine and semi-human character. This last factor was of extreme importance and it was the main reason the film was met in India with a critical reception.

In opposition to the European, or to be more precise, Peter Brook's version of the Mahabharata, the Indian one is a film of a soap-opera type. It was shown on Indian TV during more or less the same period but the film was divided into many short parts aired every week for about a year. The director of this series was Ravi Chopra.

36 Quotation from 'Peter Brook's Mahabharata' included in P. Lal (ed.), Vyasa's Mahabharata, Creative Insights, Calcutta 1992, pp. 247-270.

37 A. Lal, 'From Sagar to Brook' in idem (ed.), Vyasa's Mahabharata..., pp. 291-296. 
The film was directed mostly at Indian public. It was enormously long (ninety three episodes in total). When it was broadcasted, Indian streets were becoming empty. Ananda Chopra in his book Television and Popular Culture records that nearly 92 per cent of the Indian television viewers were watching the serial. ${ }^{38}$ Another version was the video one. These were forty eight 90-minutes-long cassettes which altogether made a 72-hour-long video story. In Europe, the TV series was shown at late hours by BBC and some of the fragments were presented by French TV..$^{39}$ Nowadays, at the beginning of the $21^{\text {st }}$ century, Europeans are more interested in this or other modern Indian versions of the epic. They can obtain these films with the help of YouTube. The length of the Indian soap-opera version certainly resembles the original Mahabharata better than the European one. It is also closer to the original as far as the number of heroines and heroes participating in particular episodes is concerned. There are hundreds of them. The choreography is also very different from the European version. The screen is full of colours, it glimmes with silver and gold. Special effects are common and included mostly in the parts where the gods appear. They are connected especially with Krishna. The audience is given many static scenes in which there are only monologues and dialogues between different characters. Some of the scenes (like the one with a riding king) are repeated many times in exactly the same form. The prevailing idea was to show the main plot intermingled with as many sub-stories as possible. The narration frames these stories by means of occasional voice-over. Sometimes the narrator enlightens the public with the so-called "words of wisdom." In this version Krishna is clearly shown as a God. Many scenes presenting his childhood and later life have been included even if they are not fragments of the original epic. When doing research on the different reception of Indian version in Europe and European version in India I have found that maybe this last factor, that is the image of Krishna, was of the greatest importance in regard to the Indian reception of the European version. Indians could have accepted Brook's version (or vision) as at least partly their own but the image of Krishna shown by him made them intolerant of also the other characteristic features of his version of the epic. The language of Indian Mahabharata was Hindi and it was Hindi spoken mainly in North-Central India, particularly around the area which is considered to be the childhood playground of Krishna. Ravi Chopra's series was made by Indian people for an Indian audience. The director did not focus on cross-cultural values. The goal was rather to re-call and repeat what has been always known by Indian society. Nevertheless, this version can take the European audience to the world of ancient India where time moves slowly and people have patience to listen to stories again and again. It shows the abundance of colours of the land and tempts to further explore this unknown culture. It may definitely be treated as one more bridge to understand India.

When we hear or read story coming from what we can call "our" or the "other" tradition we definitely build our own version of it. This version is based on our own cultural

\footnotetext{
38 A. Mitra, Television and Popular Culture in India. A Study of the Mahabharat, New Delhi 1993, p. 90.

39 In Great Britain the main target was the Indian diaspora.
} 
roots and background but also on the knowledge of one's own and other cultures. Even within one's own tradition the images which come to mind of different recipients can vary distinctly. Especially when it comes to the understanding and visualisation of an ancient past. The bridges to be build are not only of a language or cultural nature, but the space to be covered is also the topic of past and present. Can we really precisely imagine how the world of our past or of different cultures' past looked many centuries or thousands of years ago? Does anybody have the right to claim that her or his very vision is the only one possible? Can we objectively or at least inter-objectively claim we understand the words used in languages other than our own (if even in our own language we can have different associations depending on our own experience, knowledge, powers of imagination etc.)? Can we value or disvalue Peter Brook's or the Indian version of the Mahabharata epic? At least some of the images built by each person are based on historical or cultural details coming from different sources but there is always, in my opinion, a large margin left for the individual power of imagination. The problem is to what extent these imaginary pictures of individuals can be compatible with each other and can form the basis for communication. Do these problems multiply when the individuals come from different cultural backgrounds? Is it possible to trespass spaces of these differences, to make intercultural walks possible? Definitely, at least to some extent, my answer is a sound "yes."

\section{BIBLIOGRAPHY}

Bopp F., Glossarium comparativum linguae sanscritae in quo omnes sanscritae radices et vocabula usitatissima explicantur et cum vocalibus graecis, latinis, germanicis, lituanicis, slavicis, celticis comparantur, Berlin 1828.

Bopp F., Kritische Grammatik der Sanskrit Sprache in kürzerer Fassung, Berlin 1832.

Brockington J.L., The Sanskrit Epics, Leiden 1998 (Handbuch der Orientalistik).

Bronkhorst J., 'L'Indianisme et les préjugés occidentaux', Études de Lettres. Revue de la Faculté des Lettres, Lausanne, No. 2 (1989).

Bronkhorst J., Greater Magadha. Studies in the Culture of Early India, Leiden 2007 (Handbuch der Orientalistik).

Buitenen J.A.B. van, 'Introduction' in The Mahabharata, Book 3: The Book of the Forest, Chicago-London 1975.

Byrski M.K., 'O czym mówi literatura indyjska, czyli współrzędne indyjskiej rzeczywistości', Literatura na Świecie, Vol. 10 (1980).

Carey W., A Grammar of the Sungskrit language, composed from the works of the most esteemed Grammarians, to which are added examples for the exercises of the student, and a complete list of the dhatoos, or roots, Serampore 1806.

Carrière J. C., The Mahabharata. A Play Based upon the Indian Classical Epic, trans. by P. Brook, London 1988 (Methuen Modern Plays).

Carrière J.C., Le Mahabharata, Paris 1985 (Créations Théâtrales)

Colebrooke H.Th., A Grammar of the Sanskrit Language, Vol. 1, Calcutta 1805. 
A Dictionary in Sanskrit and English, translated, amended, and enlarged from an original compilation, prepared by learned natives for the College of Fort William by H.H. Wilson, Calcutta 1819.

Doniger O'Flaherty W., 'Introduction' in The Rig veda. An Anthology, Harmondsworth-New York 1984 (Penguin Classics).

Fitzgerald J., 'Dharma and its Translation in the Mahabharata,' Journal of Indian Philosophy, Vol. 32, No. 5/6 (2004).

Gombrich R., On Being Sanskritic. A Plea for Civilized Study and the Study of Civilisation. An Inaugural Lecture Delivered before the University of Oxford on 14 October 1977, Oxford 1978 (Inaugural Lectures, University of Oxford).

Halbfass W., Indien und Europa. Perspektiven ihrer geistigen Begegnung, Basel 1981.

Hauschild R., 'Notes on the Content of the Three Manuscripts of Heinrich Roth' inThe Sanskrit Grammar and manuscripts of Father Heinrich Roth, S.J. (1620-1668), facsimile ed. of Biblioteca Nazionale, Rome, Mss. Or. 171 and 172, Leiden 1988.

Johnson W.J., 'Introduction' in The Sauptikaparvan of the Mahabharata. The Massacre at Night, trans. with an introduction and notes by W.J. Johnston, Oxford-New York 1998 (Oxford World's Classics).

Jones W., A Desriptive Poem by Calidas in the original Sanscrit, Calcutta 1792.

Karttunen K., 'Some Thoughts about Edward Said, Hindutva and Western Indology', Cracow Indological Studies, Vol. 10 (2008).

Keith A.B., A History of Sanskrit Literature, London 1928 (repr. 1996).

Lal P. (ed.), Vyasa's Mahabharata, Creative Insights, Calcutta 1992.

Macdonell A.A., A History of Sanskrit Literature, London 1900 (repr. 1990).

The Mahabharata, ed. V.S. Sukthankar (et. al.), 19 vols., Poona 1933-1966.

Milewska I., 'Dzieje poznania sanskrytu przez Europejczyków. Najstarsza europejska gramatyka sanskrytu,' Biuletyn Glottodydaktyczny, Vol. 11 (2004).

Milewska I., 'First European Missionaries on Sanskrit Grammar' in Christians and Missionaries in India. Cross-Cultural Communication Since 1500, with Special Reference to Caste, Conversion and Colonialism, in R.E. Frykenberg (ed.), London 2003 (Studies in the History of Christian Missions).

Milewska I., 'Main Currents in the European Tradition of Sanskrit Grammars' in G. Cardona (ed.), Vyakarana Across the Ages, New Delhi 2013.

Milewska I., 'The Mahabharata Epic. Its Translations and Its Influence on Polish Intelectual Circles and General Readers', Źródta Humanistyki Europejskiej, Vol. 5 (2012).

Milewska I., 'Two Modern Film Versions of the Mahabharata. Similarities and Differencies Between an Indian and a European Approach' in M. Brockington, P. Schreiner, R. Katičić (eds.), Composing a Tradition. Concepts, Techniques and Relationships. Proceedings of the First Dubrovnik International Conference on the Sanskrit Epics and Puranas, August 1997, Zagreb 1999.

Milewska I., Ze studiów nad Mahabharata, Kraków 2013.

Mitra A., Television and Popular Culture in India. A Study of the Mahabharat, New Delhi 1993. Monier-Williams M. (ed.), A Dictionary, English and Sanscrit, London 1851 (repr. 1989).

Monier-Williams M. (ed.), A Sanskrit-English Dictionary Etymologically and Philologically Ar- 
ranged with Special Reference to Greek, Latin, Gothic, German, Anglo-Saxon, and Other Cognate Indo-European Languages, London 1872 (repr. 1995).

Muller J.-C., 'Recherches sur les premières grammaires manuscrites du Sanskrit', Bulletin d'Études Indiennes, Vol. 3 (1985), at <http://dx.doi.org/10670/1.qu2n5l>.

O'Connor G., The Mahabharata. Peter Brook's Epic in the Making, London 1989.

Paulinus a Sancto Bartholomaeo, Dissertation on Sanskrit Language. A reprint of the original Latin text of 1790, together with an introductory article, a complete English translation, and an index of sources, by L. Rocher, Amsterdam 1977 (Amsterdam Studies in the Theory and History of Linguistic Science).

Paulinus a Sancto Bartholomaeo, Sidharubam seu grammatica Samscridamica cui accedit dissertatio historico-critica in linguam samscridamicam vulgo Samscret dictam in qua huius linguae existentia, origo, praestantia, antiquitas, extensio, maternitas ostenditur, libri aliqui ea exarati critice recensentur, et simul aliquae antiquissimae gentilium orationes liturgicae paucis attinguntur et explicantur, Romae 1790.

Said E.W., Orientalism, New York 1978.

The Sanskrit Grammar and manuscripts of Father Heinrich Roth, S.J. (1620-1668), facsimile ed. of Biblioteca Nazionale, Rome, Mss. Or. 171 and 172, Leiden 1988.

Scharfe H., Grammatical Literature, in J. Gonda (ed.), A History of Indian Literature, Vol. 5, fasc. 2, Wiesbaden 1977.

Sebeok Th.A., Portraits of Linguists. A Biographical Source Book for the History of Western Linguistics, 1746-1963, Vol. 1-2, Bloomington 1966 (Indiana University Studies in the History and Theory of Linguistics).

Syed R., Die Flora Altindiens in Literature und Kunst, Doktorgrades der Philosophie Universität München, 1990.

Varadpande M.L., Mahabharata in Performance, New Delhi 1990.

Williams D. (ed.), Peter Brook and the Mahabharata. Critical Perspectives, London 1991.

Winternitz M., Geschichte der indischen Litteratur, 3 vols., Leipzig 1905-1922 (English trans. A History of Indian Literauture, Vol. 3, Part 1, reprint Delhi 1963).

Iwona MILEWSKA, Ph.D. - Associate Professor at the Institute of Oriental Studies, Jagiellonian University, Kraków, Poland. She specializes in ancient Indian and South Asian culture. Within these fields Sanskrit epics are of her special interest. In her works she covers also intercultural communication and glottodidactics of languages. Her recent publications include the book and articles on one of the Sanskrit epics, Mababharata, on the European tradition of Sanskrit grammars and on inter-cultural relations and understanding. 